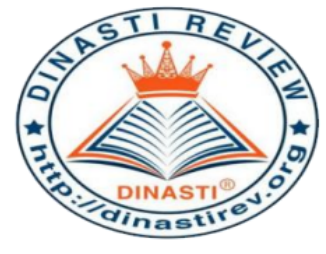

+62 878-9658-6407

087896586407

https://dinastirev.org/JIMT

editor@dinastirev.org

\title{
PENGARUH PENGETAHUAN KEWIRAUSAHAAN, MEDIA SOSIAL, DAN MOTIVASI BERWIRAUSAHA TERHADAP MINAT BERWIRAUSAHA SISWA/I PADA SMK NEGERI 1 KOTA SUNGAI PENUH
}

\author{
Suratno $^{1}$, Farida Kohar ${ }^{2}$, Rosmiati ${ }^{3}$, Ari Kurniawan ${ }^{4}$ \\ 1) Dosen Universitas Jambi, Jambi, Indonesia \\ 2) Dosen Universitas Jambi, Jambi, Indonesia \\ 3) Dosen Universitas Jambi, Jambi, Indonesia \\ 4) Alumni Program Studi Magister Pendidikan Universitas Jambi, Jambi, Indonesia
}

\begin{tabular}{|c|c|}
\hline $\begin{array}{l}\text { ARTICLE INFORMATION } \\
\text { Received: } 15 \text { April } 2020 \\
\text { Revised: 25 April } 2020 \\
\text { Issued: } 5 \text { Mei } 2020 \\
\text { Corresponding Author: } \\
\text { E-mail: } \underline{\text { suratnounja@gmail.com }} \\
\underline{\text { rosmiati.fkip@ unja.ac.id }} \\
\underline{\text { aksahud13@gmail.com }}\end{array}$ & $\begin{array}{l}\text { Abstract: Tujuan penelitian ini untuk mengetahui: 1) pengaruh } \\
\text { pengetahuan kewirausahaan terhadap motivasi berwirausaha; 2) } \\
\text { pengaruh media sosial terhadap motivasi berwirausaha; 3) pengaruh } \\
\text { pengetahuan kewirausahaan dan media sosial secara simultan } \\
\text { terhadap motivasi berwirausaha; 4) pengaruh pengetahuan } \\
\text { kewirausahaan terhadap minat berwirausaha; 5) pengaruh media } \\
\text { sosial terhadap minat berwirausaha; 6) pengaruh motivasi } \\
\text { berwirausaha terhadap minat berwirausaha; dan 7) pengaruh } \\
\text { pengetahuan kewirausahaan, media sosial dan motivasi } \\
\text { berwirausaha secara simultan terhadap minat berwirausaha. } \\
\text { Pengujian ini dilakukan dengan analisis jalur (path analisys) yang } \\
\text { dilanjutkan dengan uji t dan uji F untuk pengujian hipotesis dengan } \\
\text { menggunakan alat bantu SPSS } 21.0 \text {. for windows. Populasi dalam } \\
\text { penelitian ini adalah siswa-siswi Sekolah Menengah Kejuruan } \\
\text { Negeri } 1 \text { Kota Sungai Penuh yang terdiri dari Sembilan kelas } \\
\text { dengan jumlah 293 siswa/I. Hasil penelitian ini menyimpulkan: 1) } \\
\text { pengetahuan kewirausahaan memiliki pengaruh yang positif dan } \\
\text { signifikan terhadap motivasi berwirausaha; } 2 \text { ) media sosial memiliki } \\
\text { pengaruh yang positif dan signifikan terhadap motivasi } \\
\text { berwirausaha; 3) pengetahuan kewirausahaan dan media sosial } \\
\text { secara simultan memiliki pengaruh yang positif dan signifikan } \\
\text { terhadap motivasi berwirausaha; 4) pengetahuan kewirausahaan } \\
\text { memiliki pengaruh yang positif dan signifikan terhadap minat } \\
\text { berwirausaha; 5) media sosial memiliki pengaruh yang positif dan } \\
\text { signifikan terhadap minat berwirausaha; } 6 \text { ) motivasi berwirausaha } \\
\text { memiliki pengaruh yang positif dan signifikan terhadap minat } \\
\text { berwirausaha; dan 7) pengetahuan kewirausahaan, media social, dan } \\
\text { motivasi berwirausaha secara bersama-sama (simultan) memiliki } \\
\text { pengaruh yang positif dan signifikan terhadap minat berwirausaha } \\
\text { siswa/I SMK Negeri } 1 \text { Kota Sungai Penuh. } \\
\text { Kata Kunci: Pengetahuan Kewirausahaan, Media Sosial, Motivasi } \\
\text { Berwirausaha, dan Minat Berwirauasa. }\end{array}$ \\
\hline
\end{tabular}

\section{PENDAHULUAN}

Pengangguran bukanlah merupakan hal baru di Indonesia, apalagi diera globalisasi di mana tingkat persaingan mencari kerja semakin kompetitif, sementara lapangan pekerjaan yang tersedia semakin terbatas. Apalagi jika melihat setiap tahunnya jumlah lulusan sekolah 
sangatlah banyak, dan kebanyakan lulusan lebih banyak mengarahkan langkahnya untuk mencari pekerjaan. Jika kondisi saat ini terus berlanjut, maka pada saatnya nanti akan semakin banyak pengangguran terdidik, pengangguran intelektual. Hal ini belum termasuk para lulusan perguruan tinggi yang ternyata juga masih harus mencari pekerjaan.

Melihat kondisi ini tentunya perlu solusi untuk memecahkan masalah tersebut. Di mana salah satunya yaitu siswa dan kaum muda dituntut untuk dapat berpikir kreatif untuk menjadi seorang entrepreneurship, dan Sekolah mempunyai peranan penting untuk hal itu, dimana dalam upaya mengarahkan anak didik mempunyai kesadaran bahwa berwirausaha merupakan alternatif terpenting menghadapi kehidupan yang semakin ketat persaingannya. Hal ini mengandung pengertian bahwa sekolah dapat dijadikan sebagai media untuk menarik minat siswa/I untuk menjadi seorang entrepreneur melalui pendidikan di sekolah setelah mereka lulus kelak.

Meskipun sekolah telah berupaya untuk menumbuhkan minat siswa/I untuk berwirausaha melalui pendidikan. Namun ternyata sekolah-sekolah masih belum mampu menghasilkan siswa/I yang siap berwirausaha dengan mandiri. Usaha sekolah dengan memasukan mata pelajaran kewirausahaan belum begitu tampak hasilnya. Masih rendahnya minat masyarakat untuk menjadi seorang entrepreneur, terkait masih banyaknya masyarakat mengarahkan langkahnya untuk mencari pekerjaan. Hal ini tentu saja nantinya akan berdampak terhadap semakin meningkatnya jumlah pengangguran, karena tingkat persaingan mencari kerja semakin kompetitif, sementara lapangan pekerjaan yang tersedia semakin terbatas. Apalagi jika melihat setiap tahunnya jumlah lulusan sekolah sangatlah banyak, dan kebanyakan lulusan lebih banyak mengarahkan langkahnya untuk mencari pekerjaan. Jika kondisi saat ini terus berlanjut, maka pada saatnya nanti akan semakin banyak pengangguran terdidik, pengangguran intelektual. Hal ini belum termasuk para lulusan perguruan tinggi yang ternyata juga masih harus mencari pekerjaan.

Melihat kondisi ini tentunya perlu solusi untuk memecahkan masalah tersebut. Dimana salah satunya yaitu siswa dan kaum muda dituntut untuk dapat berpikir kreatif untuk menjadi seorang entrepreneurship, dan Sekolah mempunyai peranan penting untuk hal itu, di mana dalam upaya mengarahkan anak didik mempunyai kesadaran bahwa berwirausaha merupakan alternatif terpenting menghadapi kehidupan yang semakin ketat persaingannya. Hal ini mengandung arti bahwa sekolah dapat dijadikan sebagai media untuk menarik minat siswa/I untuk menjadi seorang entrepreneur melalui pendidikan di sekolah setelah mereka lulus kelak.

Minat berperan sangat penting dalam kehidupan peserta didik dan mempunyai dampak yang besar terhadap sikap dan perilaku. Siswa yang memiliki minat terhadap sesuatu cenderung mempunyai ketertarikan untuk mengetahui dan mempelajari hal-hal yang berkaitan dengan minat tanpa adanya paksaan. Minat berwirausaha akan menjadikan seseorang lebih giat mencari dan memanfaatkan peluang usaha dengan mengoptimalkan potensi yang dimiliki. Minat berwirausaha merupakan keinginan, ketertarikan, serta kesediaan individu untuk bekerja keras dalam memenuhi kebutuhan hidupnya tanpa takut dengan resiko yang akan terjadi. Seseorang dikatakan memiliki minat berwirausaha yang tinggi dapat dilihat dari berbagai aspek kepribadian seperti watak, sikap dan perilaku seseorang (Anggraeni, B dan Harnanik, 2015: 43). 
Menurut Slameto dalam Khairani (2013: 2) bahwa minat sebagai salah satu aspek psikologis dipengaruhi oleh beberapa faktor, baik yang sifatnya dari dalam (internal) maupun dari luar (eksternal). Dilihat dari dalam diri siswa, minat dipengaruhi cita-cita, kepuasan, motivasi, kebutuhan, bakat, dan pengetahuan. Sedangkan bila dilihat dari faktor luarnya minat sifatnya tidak menetap melainkan dapat berubah sesuai dengan kondisi lingkungan. Faktor luar tersebut dapat berupa kelengkapan sarana dan prasarana, pergaulan dengan orang tua dan persepsi masyarakat terhadap suatu objek serta latar belakang sosial budaya.

Berdasarkan paparan di atas, menarik untuk dikaji lebih jauh mengenai minat berwirausaha siswa pada SMK Negeri 1 Kota Sungai Penuh dalam hubunganya dengan aspek-aspek yang berkaitan dengan pengetahuan kewirausahaan, media sosial, dan motivasi berwirausaha. Untuk itu, judul diangkat dalam penelitian ini adalah "Pengaruh Pengetahuan Kewirausahaan, Media Sosial dan Motivasi Berwirausaha Terhadap Minat Berwirausaha Siswa/I Pada SMK Negeri 1 Kota Sungai Penuh".

Berdasarkan uraian latar belakang dan perumusan masalah maka tujuan yang ingin dicapai dari penelitian ini yaitu: 1) Untuk melihat pengaruh pengetahuan kewirausahaan terhadap motivasi berwirausaha; 2) Untuk melihat pengaruh media sosial terhadap motivasi berwirausaha; 3) Untuk melihat pengaruh pengetahuan kewirausahaan terhadap minat berwirausaha; 4) Untuk melihat pengaruh media sosial terhadap minat berwirausaha; 5) Untuk melihat pengaruh motivasi berwirausaha terhadap minat berwirausaha; 6) Untuk melihat pengaruh pengetahuan kewirausahaan melalui motivasi berwirausaha terhadap minat berwirausaha; dan 7) Untuk melihat pengaruh media sosial melalui motivasi berwirausaha terhadap minat berwirausaha.

\section{KAJIAN PUSTAKA}

\section{Minat Berwirausaha}

Minat wirausaha merupakan kemampuan untuk mendorong diri sendiri dan berbuat sesuatu untuk memenuhi kebutuhan hidup serta pemecahan permasalahan hidup, memajukan usaha atau menciptakan usaha baru dengan perasaan senang karena membawa manfaat bagi dirinya untuk berusaha memenuhi kebutuhan hidupnya tanpa merasa takut akan resiko yang akan dihadapi, senantiasa belajar dari kegagalan yang dialami, serta mengembangkan usaha yang diciptakannya (Hendrawan, J.S., dan Sirine, H., 2017: 297).

Menurut Sampurna, A.A (2015: 5) minat berwirausaha dapat diartikan sebagai suatu keinginan yang timbul dari diri seseorang untuk membuka usaha dengan berani mengambil resiko dalam berbagai kesempatan. Minat berwirausaha perlu ditumbuh kembangkan oleh peserta didik untuk mempersiapkan menghadapi dunia kerja yang semakin sempit peluangnya di masa yang akan datang. Sedangkan menurut Aprilia, dkk (2012: 2) minat berwirausaha merupakan rasa tertariknya seseorang untuk melakukan kegiatan usaha yang mandiri dengan keberanian mengambil risiko. Minat berwirausaha bisa datang dari dalam individu siswa itu sendiri mapun dari luar.

Haqq, H.I., Sebayang, A.F., dan Haviz, M (2018: 144) minat wirausaha adalah keinginan, ketertarikan serta kesediaan untuk bekerja keras atau berkemauan keras dengan adanya pemusatan perhatian untuk berusaha memenuhi kebutuhan hidupnya tanpa merasa 
takut akan resiko yang akan dihadapi, senantiasa belajar dari kegagalan yang dialami, serta mengembangkan usaha yang diciptakannya.

Berdasarkan uraian di atas, dapat disimpulkan bahwa minat berwirausaha adalah ketertarikan, perhatian, keinginan lebih yang dimiliki seseorang untuk bertindak secara kreatif dan inovatif untuk menghasilkan sesuatu secara mandiri dan tanggung jawab, yang tercermin melalui indikator yaitu 1) Adanya rasa ketertarikan terhadap dunia wirausaha; 2) Memperhatikan segala sesuatu yang berhubungan dengan kewirausahaan; 3) Adanya keterlibatan secara aktif pada kegiatan yang berhubungan dengan kewirausahaan; dan 4) Berorientasi ke masa depan.

\section{Motivasi Berwirausaha.}

Motivasi merupakan proses psikologi yang mendasar, dan merupakan salah satu unsur yang dapat menjelaskan perilaku seseorang. Motivasi merupakan salah satu faktor penentu dalam pencapaian tujuan. Motivasi berhubungan dengan dorongan atau kekuatan yang berada dalam diri manusia. Motivasi berada dalam diri manusia yang tidak terlihat dari luar. Motivasi menggearakan manusia untuk menampilkan tingkah laku kearah pencapaian suatu tujuan tertentu (Suryana, Y dan Bayu, K., 2014: 98).

Motivasi merupakan faktor yang sangat berpengaruh pada diri seseorang untuk menentukan apa yang menjadi keinginan dan usahanya untuk mewujudkan keinginannya tersebut. Menurut Uno Motivasi adalah dorongan dasar yang menggerakkan seseorang bertingkah laku. Rusdiana Motivasi dapat dipahami sebagai keadaan dalam diri individu yang menyebabkan mereka berperilaku dengan cara yang menjamin tercapainya suatu tujuan. Sarosa juga berpendapat bahwa motivasi adalah suatu dorongan dari dalam diri seseorang yang mendorong orang tersebut untuk melakukan sesuatu, termasuk menjadi young entrepreneur. Machfoedz mengemukakan bahwa motivasi adalah dorongan dan arahan perilaku (Hendrawan, J.S., dan Sirine, H., 2017:298).

Berdasarkan uraian di atas, dapat disimpulkan bahwa motivasi berwirausaha merupakan dorongan psikologis dari dalam maupun luar diri seseorang untuk bisa melakukan wirausaha. Dengan adanya dorongan tersebut, seseorang dapat menentukan usaha apa yang akan dikelolanya sekaligus juga dapat menentukan nasibnya dimasa depan. Adapun indikator motivasi berwirausaha yang digunakan dalam penelitian ini mengacu pada teori yang dikemukakan oleh Saiman (2014: 26) dan Hierarki kebutuhan menurut Maslow dengan indikator laba, kebebasan, impian personal, kemandirian, kebutuhan fisiologi/dasar (basic need), kebutuhn rasa aman (safety need), Kebutuhan sosial (social need), dan kebutuhan pengakuan diri (self actualization).

\section{Pengetahuan Berwirausaha}

Pengetahuan kewirausahaan adalah pemahaman seseorang mengenai dunia usaha yang diwujudkan melalui gagasan inovatif ke dalam dunia nyata secara kreatif dan inovatif dalam mengembangkan peluang-peluang usaha menjadi kesempatan usaha. Pernyataan ini diperkuat oleh pernyataan Mustofa dalam Hendrawan, J.S., dan Sirine, H (2017:299) bahwa pengetahuan kewirausahaan adalah kemampuan seseorang untuk menghasilkan sesuatu yang baru melalui berpikir kreatif dan bertindak inovatif, sehingga dapat menciptakan ide-ide atau peluang dan dapat dimanfaatkan dengan baik. 
Pengetahuan wirausaha menurut Kuntowicaksono (2012: 47) sebagai pemahaman seseorang terhadap wirausaha dengan berbagai karakter positif, kreatif, dan inovatif dalam mengembangkan peluang-peluang usaha menjadi kesempatan usaha yang menguntukan dirinya dan masyarakat atau konsumennya. Lebih lanjut Kuntowicaksono (2012: 49) menjelaskan bahwa pengetahuan wirausaha merupakan salah satu aspek penting dalam berwirausaha karena dengan adanya pengetahuan yang memadai atau cukup, maka seseorang akan dapat mengelola usaha dengan baik.

Menurut Tung (2011: 63) pengetahuan kewirausahaan meliputi beberapa komponen yaitu: penyusunan sumber daya serta keuangan, pemasaran serta keahlian menjual, ide tentang sesuatu yang baru/berbeda serta penemuan peluang, perencanaan bisnis, membangun tim, penciptaan usaha baru, manajemen risiko, masalah hukum, dan manajemen organisasi. Menurut Plaschka dan Welsch (Tung, 2011: 63) meliputi: pengetahuan mengenai negosiasi, kepemimpinan, berpikir kreatif, teknologi, inovasi serta pengembangan produk baru.

Berdasarkan uraian di atas, dapat disimpulkan bahwa pengetahuan kewirausahaan adalah pemahaman seseorang mengenai dunia usaha yang diwujudkan melalui gagasan inovatif ke dalam dunia nyata secara kreatif dan inovatif dalam mengembangkan peluangpeluang usaha menjadi kesempatan usaha, yang diukur melalui indikator yaitu: 1) Pengetahuan mengenai usaha yang akan dirintis; 2) Pengetahuan tentang peran dan tanggung jawab; 3) Pengetahuan tentang kepribadian dan kemampuan diri; dan 4) Pengetahuan tentang manajemen dan organisasi bisnis.

\section{Media Sosial}

Social media merupakan media komunikasi yang interaktif (Sari, I.P dan Maya, S., 2017: 163). Menurut Sari, I.P dan Maya, S (2017: 164) dalam suatu kegiatan bisnis penggunaan social media adalah untuk komunikasi personal dengan konsumen, pemasaran dan iklan, mendata kebutuhan konsumen, memberikan respon pada konsumen, membantu pengambilan keputusan dan sebagai forum diskusi dengan konsumen.

Menurut Kotler dan Keller (2012: 568), media sosial merupakan sarana bagi konsumen untuk berbagi informasi teks, gambar, audio, dan video dengan satu sama lain dan dengan perusahaan dan sebaliknya. Peran media sosial semakin diakui dalam mendongkrak kinerja bisnis. Media sosial memungkinkan bisnis kecil dapat mengubah cara berkomunikasi dengan pelanggan, memasarkan produk dan jasa serta saling berinteraksi dengan pelanggan yang bertujuan untuk membangun hubungan yang baik.

Shirky dalam Nasrullah (2015: 11) mengemukakan bahwa media sosial dan perangkat lunak sosial merupakan alat untuk meningkatkan kemampuan pengguna untuk berbagi (to share), bekerja sama (to co-operate) diantara pengguna dan melakukan tindakan secara kolektif yang semuanya berada diluar kerangka institusional maupun organisasi.

Berdasarkan uraian di atas, dapat disimpulkan bahwa media social merupakan media interaksi antara seseorang dengan orang lainnya yang dilakukan secara online tanpa batas ruang dan waktu. Artinya pesan yang disampaikan tidak hanya untuk satu orang saja namun bisa ke berbagai banyak orang. Selain itu pesan yang disampaikan bebas, tanpa harus melalui suatu Gatekeeper. Kemudian pesan yang disampaikan cenderung lebih cepat dibanding media lainnya, serta penerima pesan yang menentukan waktu interaksi, yang 
diukur melalui indikator yaitu: 1) Partisipasi; 2) Keterbukaan; 3) Percakapan; 4) Komunikasi; 5) Saling Terhubung; dan 6) Keterampilan siswa menggunakan media sosial.

\section{Kerangka Pemikiran}

Berdasarkan pemaparan teori dan kajian dari penelitian terdahulu di atas, maka untuk menjawab permasalahan penelitian dibentuk kerangka pemikiran seperti terlihat pada gambar berikut.

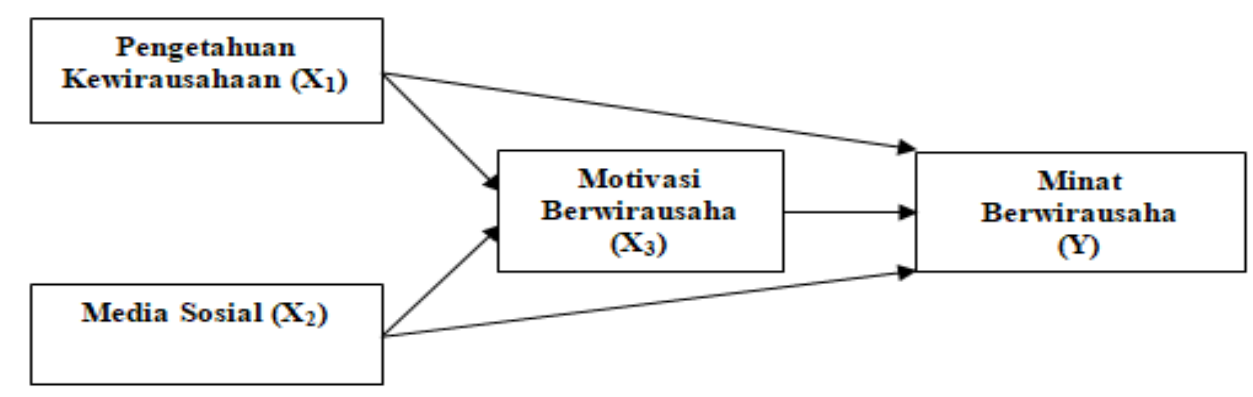

Gambar 1. Kerangka Berpikir

\section{Hipotesis}

Berdasarkan rumusan masalah dan beberapa asumsi yang telah dikemukakan terdahulu dapat dirumuskan hipotesis yang merupakan dugaan sementara. Penulis merumuskan hipotesis berkenaan dengan masalah yang diteliti sebagai berikut:

$\mathrm{H}_{1}$ : Pengetahuan kewirausahaan berpengaruh terhadap motivasi berwirausaha.

$\mathrm{H}_{2}$ : Media sosial berpengaruh terhadap motivasi berwirausaha.

$\mathrm{H}_{3}$ : Pengetahuan kewirausahaan berpengaruh terhadap minat berwirausaha.

$\mathrm{H}_{4}$ : Media sosial berpengaruh terhadap minat berwirausaha.

$\mathrm{H}_{5}$ : Motivasi berwirausaha berpengaruh terhadap minat berwirausaha.

$\mathrm{H}_{6}$ : Pengetahuan kewirausahaan berpengaruh melalui motivasi berwirausaha terhadap minat berwirausaha.

$\mathrm{H}_{7}$ : Media sosial berpengaruh melalui motivasi berwirausaha terhadap minat berwirausaha.

\section{METODE PENELITIAN}

Penelitian ini termasuk dalam golongan asosiatif kausalitas. Digolongkan asosiatif karena penelitian ini untuk mengetahui ada atau tidaknya hubungan antar variable yang di teliti. Dikategorikan kausalitas, karena penelitian ini bertujuan untuk mengetahui apakah variable-variabel yang di amati mempunyai hubungan sebab akibat tertentu seperti yang diduga secara teoritis. Untuk menjawab semua hipotesis yang telah tersusun tersebut peneliti menggunakan kuesioner dan soal test sebagai alat untuk memperoleh informasi, kemudian memberikan tanggung jawab kepada responden untuk menjawab pertanyaan- pertanyaan yang telah disediakan serta memberikan tanggapan atas pertanyaan- pertanyaan yang diajukan.

Berdasarkan tujuan penelitian, penelitian ini dikategorikan sebagai penelitian penjelas (eksplanatory research) yaitu suatu penelitian yang menjelaskan masing-masing variable melalui pengujian hipotesis. Dimana pengujian ini dilakukan dengan analisis jalur (path 
analisys) yang dilanjutkan dengan uji $\mathrm{t}$ dan uji $\mathrm{F}$ untuk pengujian hipotesis dengan menggunakan alat bantu SPSS 21.0. for windows.

Adapun populasi dalam penelitian ini adalah siswa-siswi kelas XII Sekolah Menengah Kejuruan Negeri 1 Kota Sungai Penuh yang terdiri dari empat kelas dengan jumlah 115 siswa/I. Adapun teknik penarikan sampel dalam penelitian ini menggunakan Sampling Jenuh (Sampling Sensus). Sampel jenuh digunakan dalam penelitian ini dikarenakan pada penelitian ini teknik analisis data yang digunakan adalah analisis jalur (path Analisys) yang membutuhkan populasi yang besar, sehingga semua populasi dalam penelitian ini diikutsertakan dalam penelitian ini.

Penelitian ini menggunakan analisis analisis jalur (Path Analysis). Analisis ini merupakan salah satu pilihan dalam rangka mempelajari ketergantungan sejumlah variabel didalam model. Analisis ini merupakan metode yang baik untuk menerangkan apabila terdapat seperangkat data yang besar untuk dianalisis dan mencari hubungan kausal. Path analysis merupakan salah satu alat analisis yang dikembangkan oleh (Dillon and Goldstein dalam Ali, H dan Limakrisna, N, 2013). Wright mengembangkan metode untuk mengetahui pengaruh langsung dan tidak langsung dari suatu variable, dimana terdapat variable yang memberikan pengaruh (eksogenus variables) dan variable yang dipengaruhi (endogenus variables).

\section{HASIL DAN PEMBAHASAN \\ Deskripsi Variabel Penelitian}

Berdasarkan jawaban responden dapat diberikan gambaran atau deskripsi terkait dengan variabel yang fokus pembahasan. Dimana gambaran tersebut dapat diuraikan sebagai berikut.

1) Berdasarkan hasil tes yang dilakukan kepada siswa/I, diperoleh hasil bahwasanya rata-rata siswa yang menjawab benar sebanyak 54,96 persen, dan siswa yang menjawab salah sebanyak 45,04 persen. Apabila dilihat pada rentang penilaian, pengetahuan siswa/I pada SMK Negeri 1 Kota Sungai Penuh termasuk pada range 40 - 60 berada pada Kriteria cukup baik, yang menjelaskan bahwa siswa/I pada SMK Negeri 1 Kota Sungai Penuh memiliki pengetahuan kewirausahaan yang cukup baik.

2) Berdasarkan hasil sebaran angket yang dilakukan, diperoleh skor rata-rata variabel media sosial sebesar 417,8, yang termasuk pada range 370,6 - 457,7 berada pada Kriteria Tinggi. Yang menjelaskan bahwasanya siswa/i pada SMK Negeri 1 Kota Sungai Penuh memiliki intensitas yang tinggi dalam menggunakan media sosial.

3) Dari hasil sebaran angket yang dilakukan, diperoleh skor rata-rata variabel motivasi berwirausaha sebesar 417,2, yang termasuk pada range 370,6 - 457,7 berada pada Kriteria Tinggi. Hal ini menjelaskan bahwasanya siswa/i pada SMK Negeri 1 Kota Sungai Penuh memiliki motivasi yang tinggi untuk berwirausaha.

4) Berdasarkan hasil sebaran angket yang dilakukan, diperoleh skor rata-rata variabel minat berwirausaha sebesar 4443,19, yang termasuk pada range 370,6 - 457,7 berada pada Kriteria Tinggi. Yang menjelaskan bahwasanya siswa/i pada SMK Negeri 1 Kota Sungai Penuh memiliki minat berwirausaha yang tinggi.

\section{Hasil Uji Normalitas}


Sebelum melangkah ke pengujian hipotesis, terlebih dahulu dilakukan uji normalitas. Pengujian dilakukan dengan menggunkan bantuan SPSS 21.0 sebagai alat bantu dalam penelitian ini diperoleh hasil bahwasanya data dalam penelitian ini berdistribusi normal, hal ini dibuktikan dari hasil nilai signifikansi (Asymp. Sig. 2-tailed) lebih besar dari 0,05, yaitu $(0,396>0,05)$ sehingga dapat disimpulkan bahwa data dalam penelitian ini berdistribusi normal.

\section{Analisis Jalur (Path Analisis)}

Analisis ini merupakan salah satu pilihan dalam rangka mempelajari ketergantungan sejumlah variabel didalam model. Analisis ini merupakan metode yang baik untuk menerangkan apabila terdapat seperangkat data yang besar untuk dianalisis dan mencari hubungan kausal.

Untuk menjawab tujuan-tujuan dalam penelitian ini, struktur utama dalam model penelitian di pecah menjadi empat sub struktur. Dimana untuk menjawab tujuan 1, dan 2 dengan sub struktur pertama, untuk menjawab tujuan 3, 4, dan 5 dengan menggunakan sub struktur kedua. Sedangkan untuk menjawab tujuan 6 dan 7 nilai yang diambil merupakan nilai output sub struktur pertama dan kedua untuk melihat pengaruh langsung dan tidak langsung. Berikut ini merupakan output SPSS dari dua struktur yang dirangkum pada tabel berikut.

Tabel 1. Output SPSS Dua Sub Struktur.

\begin{tabular}{|c|c|c|c|c|c|}
\hline \multirow[t]{2}{*}{ Model } & \multicolumn{2}{|c|}{$\begin{array}{c}\text { Unstandardized } \\
\text { Coefficients }\end{array}$} & \multirow[t]{2}{*}{ Beta } & \multirow[t]{2}{*}{$\mathbf{t}$} & \multirow[t]{2}{*}{ Sig. } \\
\hline & B & Std.Error & & & \\
\hline $\mathrm{X} 1-\mathrm{X} 3$ & 0,924 & 0,152 & 0,432 & 6,066 & 0,000 \\
\hline $\mathrm{X} 2-\mathrm{X} 3$ & 0,829 & 0,120 & 0,493 & 6,929 & 0,000 \\
\hline $\mathrm{X} 1-\mathrm{Y}$ & 0,471 & 0,111 & 0,299 & 4,259 & 0,000 \\
\hline $\mathrm{X} 2-\mathrm{Y}$ & 0,539 & 0,090 & 0,436 & 5,975 & 0,000 \\
\hline $\mathrm{X} 3-\mathrm{Y}$ & 0,179 & 0,061 & 0,243 & 2,941 & 0,004 \\
\hline
\end{tabular}

Sumber: Data diolah dari output SPSS.

Hasil output diatas di masukkan ke dalam gambar persamaan struktural sebagai berikut:

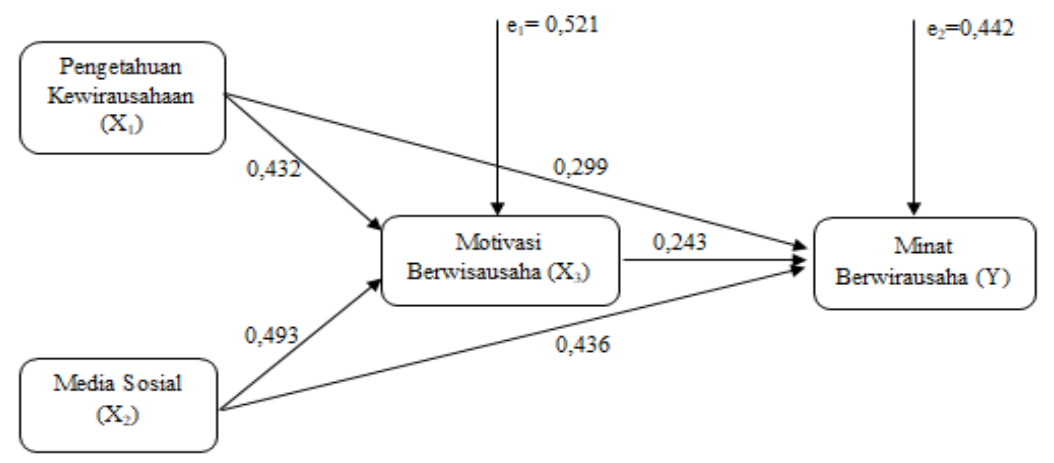

Gambar 2. Hasil Analisis Jalur

\section{1) Pengaruh Pengetahuan Kewirausahaan Terhadap Motivasi Berwirausaha.}

Dari hasil pengolahan data yang dilakukan dengan menggunakan SPSS 21.0 For Windows diperoleh nilai t-hitung variabel pengetahuan kewirausahaan sebesar 6,066, 
dikarenakan nilai t hitung > t Tabel $(6,066>1,9824)$, maka secara parsial pengetahuan kewirausahaan memiliki pengaruh terhadap motivasi berwirausaha. Oleh karena itu maka $\mathrm{H}_{0}$ ditolak, artinya secara parsial terdapat pengaruh pengetahuan kewirausahaan terhadap motivasi berwirausaha. Selain itu pula untuk melakukan uji berdasarkan pengujian signifikansi, dapat dilihat dari output signifikansi sebesar 0,000 dikarenakan angka taraf signifikansi $<0,05(0,000<0,05)$ maka dapat disimpulkan bahwa pengetahuan kewirausahaan berpengaruh terhadap motivasi berwirausaha. Artinya terdapat hubungan linier antara pengetahuan kewirausahaan dengan motivasi berwirausaha.

\section{2) Pengaruh Media Sosial Terhadap Motivasi Berwirausaha.}

Dari hasil pengolahan data yang dilakukan dengan menggunakan SPSS 21.0 For Windows diperoleh nilai t-hitung variabel media sosial sebesar 6,929, dikarenakan nilai t hitung > t Tabel $(6,929>1,9824)$, maka secara parsial media sosial memiliki pengaruh terhadap motivasi berwirausaha. Oleh karena itu maka $\mathrm{H}_{0}$ ditolak, artinya secara parsial terdapat pengaruh media sosial terhadap motivasi berwirausaha. Selain itu pula untuk melakukan uji berdasarkan pengujian signifikansi, dapat dilihat dari output signifikansi sebesar 0,000, dikarenakan angka taraf signifikansi $<0,05(0,000<0,05)$ maka dapat disimpulkan bahwa media sosial berpengaruh terhadap motivasi berwirausaha. Artinya terdapat hubungan linier antara media sosial dengan motivasi berwirausaha.

\section{3) Pengaruh Pengetahuan Kewirausahaan Terhadap Minat Berwirausaha.}

Dari hasil pengolahan data yang dilakukan seperti yang tampak pada Tabel 4.9 di atas dengan menggunakan SPSS 21.0 For Windows diperoleh nilai t-hitung variabel pengetahuan kewirausahaan sebesar 4,259, dikarenakan nilai t hitung > t Tabel $(4,259>1,9824)$, maka secara parsial pengetahuan kewirausahaan memiliki pengaruh terhadap minat berwirausaha. Oleh karena itu maka $\mathrm{H}_{0}$ ditolak, artinya secara parsial terdapat pengaruh pengetahuan kewirausahaan terhadap minat berwirausaha. Selain itu pula untuk melakukan uji berdasarkan pengujian signifikansi, dapat dilihat dari output signifikansi sebesar 0,000, dikarenakan angka taraf signifikansi $<0,05(0,000<0,05)$ maka dapat disimpulkan bahwa pengetahuan kewirausahaan berpengaruh terhadap minat berwirausaha. Artinya terdapat hubungan linier antara pengetahuan kewirausahaan dengan minat berwirausaha.

\section{4) Pengaruh Media Sosial Terhadap Minat Berwirausaha.}

Dari hasil pengolahan data yang dilakukan seperti yang tampak pada Tabel 4.9 di atas dengan menggunakan SPSS 21.0 For Windows diperoleh nilai t-hitung variabel media sosial sebesar 5,975, dikarenakan nilai t hitung > t tabel $(5,975>1,9824)$, maka secara parsial media sosial memiliki pengaruh terhadap minat berwirausaha. Oleh karena itu maka $\mathrm{H}_{0}$ ditolak, artinya secara parsial terdapat pengaruh media sosial terhadap minat berwirausaha. Selain itu pula untuk melakukan uji berdasarkan pengujian signifikansi, dapat dilihat dari output signifikansi sebesar 0,000, dikarenakan angka taraf signifikansi $<0,05(0,000<0,05)$ maka dapat disimpulkan bahwa media sosial berpengaruh terhadap minat berwirausaha. Artinya terdapat hubungan linier antara media sosial dengan minat berwirausaha.

\section{5) Pengaruh Motivasi Berwirausaha Terhadap Minat Berwirausaha.}

Dari hasil pengolahan data yang dilakukan seperti yang tampak pada Tabel 4.9 di atas dengan menggunakan SPSS 21.0 For Windows diperoleh nilai t-hitung variabel motivasi 
berwirausaha sebesar 2,941, dikarenakan nilai t hitung > t Tabel $(2,941>1,9824)$, maka secara parsial motivasi berwirausaha memiliki pengaruh terhadap minat berwirausaha. Oleh karena itu maka $\mathrm{H}_{0}$ ditolak, artinya secara parsial terdapat pengaruh motivasi berwirausaha terhadap minat berwirausaha. Selain itu pula untuk melakukan uji berdasarkan pengujian signifikansi, dapat dilihat dari output signifikansi sebesar 0,004, dikarenakan angka taraf signifikansi $<0,05(0,004<0,05)$ maka dapat disimpulkan bahwa motivasi berwirausaha berpengaruh terhadap minat berwirausaha. Artinya terdapat hubungan linier antara motivasi berwirausaha dengan minat berwirausaha.

\section{6) Pengaruh Pengetahuan Kewirausahaan Melalui Motivasi Berwirausaha Terhadap} Minat Berwirausaha.

Untuk mengetahui apakah variabel motivasi berwirausaha mampu memediasi variabel pengetahuan kewirausahan terhadap minat berwirausaha adapun langkahnya sebagai berikut.

Pengaruh langsung pengetahuan kewirausahaan terhadap minat berwirausaha

$$
\begin{aligned}
& =\operatorname{Pyx}_{1}(\mathrm{p} 1) \\
& =0,299
\end{aligned}
$$

Pengaruh tidak langsung pengetahuan kewirausahaan terhadap minat berwirausaha

$$
\begin{aligned}
& =\operatorname{Pyx}_{1}(\mathrm{p} 2) \times \operatorname{Pyx}_{3}(\mathrm{p} 3) \\
& =0,432 \times 0,243 \\
& =0,104976
\end{aligned}
$$

Total pengaruh (Pengetahuan kewirausahaan terhadap minat berwirausaha)

$$
\begin{aligned}
& =\mathrm{p} 1+(\mathrm{p} 2 \times \mathrm{p} 3) \\
& =0,299+0,104976=0,403976 .
\end{aligned}
$$

Hasil analisis jalur menunjukan bahwa pengetahuan kewirausaha dapat berpengaruh langsung terhadap minat berwirausaha dan dapat juga berpengaruh tidak langsung yaitu dari pengetahuan kewirausahaan ke motivasi berwirausaha (sebagai variabel intervening) lalu ke minat berwirausaha. Untuk mengetahui pengaruh mediasi ditunjukan oleh perkalian koefisien (p2 x p3) sebesar 0,104976 signifikan atau tidak, diuji dengan Sobel test sebagai berikut:

Hitung standar error dari koefisien indirect effect (Sp2p3)

$$
\begin{aligned}
& S p 2 p 3=\sqrt{p 3^{2} S p 2^{2}+p 2^{2} S p 3^{2}+S p 2^{2} S p 3^{2}} \\
& S p 2 p 3=\sqrt{(0,243)^{2}(0,152)^{2}+(0,432)^{2}(0,061)^{2}+(0,152)^{2}(0,061)^{2}} \\
& S p 2 p 3=\sqrt{(0,059049.0,023104)+(0,186624.0,003721)+(0,023104.0,003721)} \\
& S p 2 p 3=\sqrt{0,001364268096+0,000694427904+0,000085969984} \\
& S p 2 p 3=\sqrt{0,002144665984}=0,046
\end{aligned}
$$

Berdasarkan hasil Sp2p3 ini kita dapat menghitung nilai t statistik pengaruh mediasi dengan rumus sebagai berikut:

$\mathrm{t}=\frac{p 2 p 3}{s p 2 p 3}=\frac{0,104976}{0,046}=2,282$

Oleh karena nilai t hitung $=2,282$ lebih besar dari nilai $\mathrm{t}$ tabel dengan tingkat signifikan 0,05 yaitu 1,9824, maka dapat disimpulkan bahwa koefisien mediasi 0,104976 signifikan yang berarti bahwa motivasi berwirausaha mampu memediasi pengetahuan kewirausahaan terhadap minat berwirausaha. Artinya dengan adanya dukungan motivasi berwirausaha akan semakin meningkatkan minat siswa/I untuk berwirausaha. 


\section{7) Pengaruh Media Sosial Melalui Motivasi Berwirausaha Terhadap Minat Berwirausaha.}

Untuk mengetahui apakah variabel motivasi berwirausaha mampu memediasi variabel media sosial terhadap minat berwirausaha adapun langkahnya sebagai berikut.

Pengaruh langsung media sosial terhadap minat berwirausaha

$$
\begin{aligned}
& =\operatorname{Pyx}_{2}(\mathrm{p} 1) \\
& =0,436
\end{aligned}
$$

Pengaruh tidak langsung media sosial terhadap minat berwirausaha

$$
\begin{aligned}
& =\mathrm{Px}_{3} \mathrm{X}_{2}(\mathrm{p} 2) \times \mathrm{Pyx}_{3}(\mathrm{p} 3) \\
& =0,493 \times 0,243 \\
& =0,119799
\end{aligned}
$$

Total pengaruh (media sosial terhadap minat berwirausaha)

$$
\begin{aligned}
& =\mathrm{p} 1+(\mathrm{p} 2 \times \mathrm{p} 3) \\
& =0,436+0,119799=0,555799 .
\end{aligned}
$$

Hasil analisis jalur menunjukan bahwa media sosial dapat berpengaruh langsung terhadap minat berwirausaha dan dapat juga berpengaruh tidak langsung yaitu dari media sosial ke motivasi berwirausaha (sebagai variabel intervening) lalu ke minat berwirausaha. Untuk mengetahui pengaruh mediasi ditunjukan oleh perkalian koefisien (p2 x p3) sebesar 0,119799 signifikan atau tidak, diuji dengan Sobel test sebagai berikut:

Hitung standar error dari koefisien indirect effect (Sp2p3)

$S p 2 p 3=\sqrt{p 3^{2} S p 2^{2}+p 2^{2} S p 3^{2}+S p 2^{2} S p 3^{2}}$

$S p 2 p 3=\sqrt{(0,243)^{2}(0,120)^{2}+(0,493)^{2}(0,061)^{2}+(0,120)^{2}(0,061)^{2}}$

$S p 2 p 3=\sqrt{(0,059049.0,0144)+(0,243049.0,003721)+(0,0144.0,003721)}$

$S p 2 p 3=\sqrt{0,0008503056+0,000904385329+0,00000535824}$

Sp2p3 $=\sqrt{0,001760049169}=0,042$

Berdasarkan hasil Sp2p3 ini kita dapat menghitung nilai t statistik pengaruh mediasi dengan rumus sebagai berikut:

$\mathrm{t}=\frac{p 2 p 3}{S p 2 p 3}=\frac{0,119799}{0,042}=2,852$

Oleh karena nilai t hitung $=2,852$ lebih besar dari nilai t tabel dengan tingkat signifikan 0,05 yaitu 1,9824, maka dapat disimpulkan bahwa koefisien mediasi 0,119799 signifikan yang berarti bahwa motivasi berwirausaha mampu memediasi media social terhadap minat berirausaha. Artinya dengan adanya dukungan motivasi berwirausaha akan semakin meningkatkan minat siswa/I untuk berwirausaha.

\section{KESIMPULAN DAN SARAN}

\section{Kesimpulan}

Berdasarkan hasil penelitian dan pembahasan dalam penelitian ini, maka dapat disimpulkan sebagai berikut:

1. Pengetahuan kewirausahaan memiliki pengaruh yang positif dan signifikan terhadap motivasi berwirausaha siswa/I SMK Negeri 1 Kota Sungai Penuh. Hal ini menunjukan bahwa, jika guru ingin meningkatkan motivasi berwirausaha siswa/I melalui pengetahuan kewirausaha, maka dapat ditingkatkan melalui pengetahuan siswa 
mengenai usaha yang akan dirintis, pengetahuan siswa tentang peran dan tanggung jawab, pengetahuan siswa tentang kepribadian dan kemampuan diri, serta meningkatkan pengetahuan siswa tentang manajemen dan organisasi bisnis.

2. Media sosial memiliki pengaruh yang positif dan signifikan terhadap motivasi berwirausaha siswa/I SMK Negeri 1 Kota Sungai Penuh. Hal ini menunjukan bahwa, jika guru ingin meningkatkan motivasi berwirausaha siswa/I melalui media sosial, maka dapat ditingkatkan melalui partisipasinya menggunakan media social, keterbukaan, percakapan, komunikasi, saling terhubung, serta keterampilan siswa menggunakan media sosial.

3. Pengetahuan kewirausahaan memiliki pengaruh yang positif dan signifikan terhadap minat berwirausaha siswa/I SMK Negeri 1 Kota Sungai Penuh. Hal ini menjelaskan bahwa, jika guru ingin meningkatkan minat berwirausaha siswa/I melalui pengetahuan kewirausaha, maka dapat ditingkatkan melalui pengetahuan siswa mengenai usaha yang akan dirintis, pengetahuan siswa tentang peran dan tanggung jawab, pengetahuan siswa tentang kepribadian dan kemampuan diri, serta meningkatkan pengetahuan siswa tentang manajemen dan organisasi bisnis.

4. Media sosial memiliki pengaruh yang positif dan signifikan terhadap minat berwirausaha siswa/I SMK Negeri 1 Kota Sungai Penuh. Hal ini menunjukan bahwa, jika guru ingin meningkatkan minat berwirausaha siswa/I melalui media sosial, maka dapat ditingkatkan melalui partisipasinya menggunakan media social, keterbukaan, percakapan, komunikasi, saling terhubung, serta keterampilan siswa menggunakan media sosial.

5. Motivasi berwirausaha memiliki pengaruh yang positif dan signifikan terhadap minat berwirausaha siswa/I SMK Negeri 1 Kota Sungai Penuh. Hal ini menjelaskan bahwa, jika guru ingin meningkatkan minat berwirausaha siswa/I melalui motivasi berwirausaha, maka dapat ditingkatkan melalui dorongan psikologis dari dalam maupun luar diri siswa/i untuk bisa melakukan wirausaha.

6. Motivasi berwirausaha mampu memediasi pengetahuan kewirausahaan terhadap minat berwirausaha. Hal ini menjelaskan bahwa jika siswa/I memiliki pengetahuan yang baik mengenai kewirausahaan berupa adanya rasa ketertarikan terhadap dunia wirausaha, memperhatikan segala sesuatu yang berhubungan dengan kewirausahaan, serta adanya keterlibatan secara aktif pada kegiatan yang berhubungan dengan kewirausahaan, maka hal ini akan mendorong mahasiswa untuk berwirausaha. Jika siswa telah memiliki dorongan untuk berwirausaha, maka siswa/I pun akan berminat untuk berwirausaha.

7. Motivasi berwirausaha mampu memediasi media sosial terhadap minat berwirausaha. Hal ini menjelaskan jika siswa/I dapat memanfaatkan peran media social dengan baik, dengan memanfaatkan dan meningkatkan partisipasi, keterbukaan, percakapan, serta komunikasi siswa yang berhubungan dengan kewirausahaan pada media sosial, maka hal ini akan dapat meningkakan motivasi siswa untuk berwirausaha. Dengan adanya motivasi, akan mendorong siswa dan berminat untuk berwirausaha.

\section{Saran-saran}


Dari simpulan yang telah diperoleh maka dapat disampaikan beberapa saran sebagai berikut:

1. Diharapkan kedepan guru pada SMK Negeri 1 Kota Sungai Penuh untuk dapat meningkatkan pengetahuan kewirausahaan yang diperoleh siswa/I pada mata pelajaran kewirausahaan. Terutama untuk pengetahuan mengenai usaha yang akan dirintis. Hal ini sangat penting sekali, agar nantinya siswa memiliki gambaran serta memahami dengan baik mengenai usaha apa yang akan dirintis setelah mereka menyelesaikan studinya di sekolah.

2. Diharakan kedepan guru pada SMK Negeri 1 Kota Sungai Penuh dapat lebih mendorong perserta didiknya untuk dapat memanfaatkan fasilitas yang ada pada media social secara lebih bijak, bukan hanya sebagai sarana mengunggah foto atau video saja, melainkan sebagai sarana untuk belajar dan sarana untuk mendapatkan inspirasi berwirausaha. Karena sudah banyak sekali orang-orang yang sukses berbisnis melalui media social.

3. Diharapkan kedepan guru maupun pihak sekolah mampu menanamkan sikap optimis pada siswa/i agar mau dan mampu untuk berwirausaha. Salah satunya yaitu dengan menceritakan kisah-kisah inspiratif orang-orang yang sukses melalui berwirausaha dari usia muda. Selain itu guru juga dapat mendorong siswanya untun dapat mengikuti pelatihan kewirausahaan atau seminar, agar dapat dijadikan bekal ketika sudah lulus sekolah. Hal ini dapat dijadikan alternatif apabila impiannya bekerja pada sektor formal tidak tercapai.

4. Kedepan diharapkan pada siswa/I pada SMK Negeri 1 Kota Sungai Penuh lebih giat lagi dalam mempelajari bagaimana menjadi seseorang wirausahawan yang sukses, dengan mengikuti seminar-seminar kewirausahaan, ataupun turut serta dalam kegiatan kewirausahaan. Karena dengan semakin seringnya siswa mengikuti hal-hal yang berhubungan dengan kewirausahaan, diharapkan nanti akan semakin meningkatkan minat siswa untuk berwirausaha.

5. Penelitian ini perlu di tindak lanjuti lagi untuk melihat faktor apa saja yang dapat mempengaruhi minat berwirausaha pada siswa/I SMK Negeri 1 Kota Sungai Penuh.

6. Minat berwirausaha siswa/I pada SMK Negeri 1 Kota Sungai Penuh dapat dipengaruhi oleh faktor lain, oleh karena itu perlu kajian yang lebih komfrehensif, guna menjawab faktor lain (epsilon) yang mempengaruhi minat berwirausaha selain dari pengetahuan kewirausahaan, media sosial dan motivasi berwirausaha.

\section{DAFTAR RUJUKAN}

Ali, H., Limakrisna, N. (2013). Metodologi Penelitian (Petunjuk Praktis untuk Pemecahan Masalah Bisnis, Penyusunan Skripsi, Tesis, dan Disertasi). Yogyakarta: Deeppublish.

Anggraeni, B dan Harnanik. (2015). Pengaruh Pengetahuan Kewirausahaan dan Lingkungan Keluarga Terhadap Minat Berwirausaha Siswa Kelas XI SMK Islam Nusantara Comal Kabupaten Pemalang. Jurnal Pendidikan Ekonomi Dinamika Pendidikan, Vol. X, No. 1.

Aprilia, F., Harnanik., dan Kusumantoro. (2012). Faktor-Faktor yang Mempengaruhi Minat Berwirausaha Siswa Kelas XII SMK Negeri 1 Kandeman kabupaten Batang 2011/2012. Economic Education Analysis Journal (EEAJ), Vol. 1, No. 2. 
Haqq, H.I., Sebayang, A.F., dan Haviz, M. (2018). Faktor-Faktor yang Mempengaruhi Minar Entrepreneur (Studi Kasus: Mahasiswa Fakultas Ekonomi dan Bisnis Universitas Islam Bandung). Prosiding Ilmu Ekonomi, Volume 2, No. 2.

Hendrawan, J.S dan Sirine, H. (2017). Pengaruh Sikap Mandiri, Motivasi, Pengetahuan Kewirausahaan Terhadap Minat Berwirausaha (Studi Kasus pada Mahasiswa FEB UKSW Konsentrasi Kewirausahaan). AJIE - Asian Journal of Innovation and Entrepreneuership, Vol. 2, No. 3.

Khairani, M. (2013). Psikologi Belajar. Yogyakarta: Aswaja Pressindo.

Kotler, P \& Keller, K.L. (2012). Manajemen pemasaran, Edisi 12, Jilid 1 \&2, Terjemahan Benyamen Molan. Jakarta: PT.Indah.

Kuntowicaksono. (2012). Pengaruh Pengetahuan Wirausaha dan Kemampuan Memecahkan Masalah Wirausaha Terhadap Minat Berwirausaha Siswa Sekolah Menengah Kejuruan. Journal of Economic Education, Vol. 1, No. 1.

Nasrullah, R. (2015). Media Sosial Perspektif Komunikasi, Budaya, dan Sosioteknologi. Bandung: PT Remaja Rosdakarya.

Saiman, L. 2011. Kewirausahaan, Teori, Praktik, dan Kasus-kasus. Jakarta: Salemba Empat.

Sampurna, A.A. (2015). Minat Berwirausaha Ditinjai Dari Motivasi Berwirausaha dan Prestasi Belajar Mata pelajaran Kewirausahaan pada Siswa Kelas XI Program Keahlian Kerawitan dan Seni Tari SMK negeri 8 Surakarta Tahun Jaran 2014/2015. Artikel Publikasi Ilmiah.

Sari, I.P., \& Maya, S. (2017). Social Media dan Social Shooper Terhadap Motivasi Wirausaha pada Mahasiswa. Diskusi Panel Nasional Pendidikan Kewirausahaan LPPM Universitas Indraprasta PGRI Jakarta. Prosiding 2017 "Memajukan Kewirausahaan dalam Upaya Membangun Indonesia.

Suryana, Y. \& Bayu, K. (2014). Kewirausahaan: Pendekatan Karakteristik Wirausahawan Sukses. Jakarta: Kencana.

Tung, L. C. (2011). The Impact of Entrepreneurship Education on Entrepreneurial Intention of Engineering Students. Dissertation. City University of Hongkong: Run Run Shaw Library. 